\title{
Doi 10.5943/mycosphere/7/1/4
}

\section{Recycling of spent Pleurotus compost for production of the Agrocybe cylindracea}

\author{
Noonsong $V^{1}$, Puttakun $N^{1}$, Tinsirisuk $M^{1}$ and Seephueak $P^{1}$ \\ ${ }^{1}$ Division of Plant Science, Faculty of Agriculture, Rajamangala University of Technology Srivijava, Thung Yai, \\ Nakhon Si Thammarat, 80240, Thailand.
}

Noonsong V, Puttakun N, Tinsirisuk M, Seephueak P. 2016 - Recycling of spent Pleurotus compost for production of the Agrocybe cylindracea. Mycosphere 7(1), 36-43, Doi 10.5943/mycosphere/7/1/4

\begin{abstract}
Spent Pleurotus mushroom compost and rubber sawdust were used as a substrate for a cultivation of Agrocybe cylindracea. The five mixed ratios for spawning media were entirely spent mushroom compost, spent mushroom compost and rubber sawdust (ratio 3:1, 1:1 and 1:3 respectively) and entirely rubber sawdust. The comparisons were evaluated on number of days for full colonization of the mycelia, time to first flush, number of basidiocarp and yield on $850 \mathrm{~g}$ in plastic bag. The average higher yield of $A$. cylindracea for the formula spent mushroom compost alone were obtained $135.63 \mathrm{~g} / \mathrm{bag}$ were not significant different when they were compared with rubber sawdust only yield obtained $56.46 \mathrm{~g} / \mathrm{bag}$.
\end{abstract}

Key words - agricultural waste - mushroom - supplement

\section{Introduction}

Mushrooms are appreciated for their good taste and nutritional value. The income from edible mushrooms is an important source of revenue for farmers, especially in developing countries. Presently, in Thailand and some Asian countries, the most commonly cultivated mushrooms are oyster mushroom (Pleurotus spp.), ear mushroom (Auricularia spp.) and straw mushroom (Volvariella spp.) (Thawthong et al. 2014). Moreover, other types of mushroom such Lentinula edodes, Lentinus spp., Ganoderma spp. Macrocybe spp. and Agrocybe spp. can also be cultivated and successfully (Hanko 2001, Know \& Thatithatgoon 2004). One of them, Agrocybe cylindracea (Brig.) Singer (black poplar mushroom) is an excellent, high quality mushroom with a pleasant aroma (Uhart et al. 2008), delicious taste, and nutritive and healthy values. A. cylindracea is normally grown on a wide range of lignocellulosic material the same as is Pleurotus spp. (Sánchez 2004). Some have reported of agricultural waste studies as substrate for Agrocybe, such as on orange peel and grape stalks (Nicolini et al. 1987), poplar sawdust, barley, wheat straw, reed, rice husks, sunflower, corn cobs (Philippoussis et al. 2001, Uhart et al. 2008, Isikhuemhen et al. 2009).

The substrates used in each region depend on the locally available agricultural wastes (Cohen et al. 2002, Liang et al. 2005). In Thailand, rubber sawdust is the popular basal ingredient used in the main substrate for producing the mushroom. These mushroom sawdust wastes were partially used as organic fertilizer. The mushroom compost contains high percentage of three primary nutrients (nitrogen, $\mathrm{N}$; phosphorus, $\mathrm{P}$ or $\mathrm{P}_{2} \mathrm{O}_{5}$; potassium, $\mathrm{K}$ or $\mathrm{K}_{2} \mathrm{O}$ ) as a fertilizer. Thus a 
substantial amount of spent substrate, containing potential nutritional components for additional mushroom production, is generated in the farm of the solid waste (Rinker et al. 2004, Jonathan et al 2011).

The spent mushroom compost could be used to cultivate other edible mushrooms such as P. sajor-caju after cultivation of Lentinula edodes (Royse 1992), Coprinus conatus and Agaricus bisporus after cultivation of Ganoderma lucidum or Flamulina velutipes (Chen 1998, Zhang et al. 2013), Pleurotus abalonus or Auricularia polytricha after cultivation of Pleurotus pulmonarius (Sripheuk 2007), Pleurotus ostreatus and P. florida after cultivation of oyster mushroom (Ashrafi et al. 2014). However, the production of A. cylindracea on spent substrates used to grow $P$. pulmonarius was not reported. This study was designed to investigate the mycelial growth, time to first flush, number of basidiocarp and yield of A. cylindracea on a supplemented basal medium of spent $P$. pulmonarius compost.

\section{Materials \& Methods}

\section{Culture and their maintenance}

A culture of $A$. cylindracea was prepared by tissue transplanting technique in laboratory. The culture was multiplied on potato dextrose agar media (PDA) and maintained in glass tubes at $10^{\circ} \mathrm{C}$ for further studies.

\section{Cultivation technique}

Spawn preparation: Sorghum (Sorghum bicolor) grain spawn was prepared using the standard method (Siddhant \& Singh 2009).

Substrate preparation: The oyster mushroom ( $P$. pulmonarius) was cultivated on a rubber sawdust substrate supplemented with $20 \%$ palm oil sludge (Seephueak et al. 2014). After the final harvest the spent mushroom compost was reused as the main substrate for A. cylindracea cultivation. Before reusing, the spent mushroom compost was mixed with $5 \%$ rice bran, $2 \%$ $\mathrm{Ca}(\mathrm{OH})_{2}$ and $0.2 \% \mathrm{Mg}\left(\mathrm{SO}_{4}\right)$, on a dry weight basis. Four different formulae of substrates were used to grow A. cylindracea in plastic bags compared with the standard formula of rubber sawdust substrate (Sripheuk 2007).

Treatment 1 spent mushroom compost

Treatment 2 spent mushroom compost : rubber sawdust (3:1, w:w)

Treatment 3 spent mushroom compost : rubber sawdust $(1: 1, \mathrm{w}: \mathrm{w})$

Treatment 4 spent mushroom compost : rubber sawdust (1:3, w:w)

Treatment 5 rubber sawdust (control)

The substrates were packed in plastic bags $(850 \mathrm{~g} / \mathrm{bag})$ and the openings of the bag were plugged with cotton and secured with plastic rings. The bags were pasteurized at $100{ }^{\circ} \mathrm{C}$ for 3 hours. After the substrates cooled down, they were inoculated with 15-20 grains of sorghum mother culture. The inoculated substrate bags were incubated at room temperate $\left(28-32^{\circ} \mathrm{C}\right)$ until the substrates were fully colonized with mycelia, approximately 35 days. The bags were then exposed by opening the top of the plastic bags in a growth room for basidiocarps to fruit out.

\section{The experimental design}

The experiment was laid out in a randomized complete block design (RCBD) with 4 replications. The following data were collected; number of days for full colonization of the mycelia, time to first flush, number of basidiocarp and yield. The data were analyzed according to standard method. Means were compared using Duncan's multiple range tests. Biological efficiency was measured using the following formula:

$$
\text { Biological efficiency or B.E. }(\%)=\frac{\text { Weight of fresh mushroom basidiocarps }}{\text { Weight of dry substrate }} \times 100
$$




\section{Results}

\section{Days of mycelial growth}

The period for spawn to fully colonize the substrates had significant differences among treatment $(\mathrm{P}<0.01)$. The periods are shown in Table 1 . The period of A. cylindracea colonized the substrate of rubber sawdust (control) gave the fastest mycelial growth rate which was 36.05 days followed by the spent mushroom compost mixed with rubber sawdust 1:3, 1:1 and 3:1 w/w which were $40.10,41.03$ and 41.40 days, respectively. Whereas with the use of spent mushroom compost the spawn on the substrate tended to be the slowest mycelial growth rate which was 43.65 days.

Time to the first flush of basidiocarp started 46.50-73.00 days were significant difference among treatments $(\mathrm{P}<0.01)$. Time to the first flush was according to the number of day for full colonization of mycelia. The first flush on the substrate of rubber sawdust gave the fastest at 46.50 days followed by the substrate of spent mushroom compost mixed with rubber sawdust 1:3 and 1:1 at 53.25 and 54.25 days, and had no significant difference when compared with the spent mushroom compost only substrate, which the first flush was 54.00 days. However, time of the first flush on spent mushroom compost : rubber sawdust $(3: 1)$ trended to be the slowest which was 73.00 days (Table 1 ).

\section{Number of basidiocarps and yields}

Number of basidiocarps on $850 \mathrm{~g}$ in plastic bag of 60 days harvesting are shown in Table 2 and Fig. 1. The average higher basidiocarp of A. cylindracea from the formula spent mushroom compost were obtained 61.00 basidiocarps/bag followed by spent mushroom compost mixed with rubber sawdust 3:1, 1:1 and 1:3 were obtained 42.29, 35.75 and 35.32 basidiocarps/bag, respectively. While, the formula rubber sawdust (control) the average lowest basidiocarps were obtained 31.25 basidiocarps/bag, no difference significant $(\mathrm{P}<0.01)$.

Average mushroom yields are shown in Table 2 and Fig. 2. The highest yield $(135.63 \mathrm{~g} / \mathrm{bag}$, B.E. $=40.79 \%$ ) was obtained on spent mushroom compost. Following spent mushroom compost mixed with rubber sawdust 3:1, 1:1 and 1:3 yields were obtained $111.42,97.38$ and $84.44 \mathrm{~g} / \mathrm{bag}$ the biological efficiency (B.E.) were obtained 33.51, 29.28 and $25.40 \%$, respectively. Whereas, the lowest yield obtained on rubber sawdust was $56.46 \mathrm{~g} / \mathrm{bag}($ B.E. $=16.91 \%)$, no difference significant $(\mathrm{P}<0.01)$.

Table 1 Number of day for full colonization of mycelia and time to first flush of A. cylindracea on different ratios of spent mushroom compost : rubber sawdust substrates.

\begin{tabular}{lll}
\hline Substrate $(\mathbf{8 5 0} \mathbf{g} / \mathbf{b a g})$ & $\begin{array}{l}\text { No. of day for full } \\
\text { colonization }\end{array}$ & $\begin{array}{l}\text { Time to first } \\
\text { flush (days) }\end{array}$ \\
\hline 1. spent mushroom compost & $43.65 \pm 0.39 \mathrm{a}$ & $54.00 \pm 1.29 \mathrm{~b}$ \\
2. spent mushroom compost : rubber sawdust $(3: 1)$ & $41.40 \pm 0.42 \mathrm{~b}$ & $73.00 \pm 2.16 \mathrm{a}$ \\
3. spent mushroom compost : rubber sawdust (1:1) & $41.03 \pm 0.99 \mathrm{bc}$ & $54.25 \pm 1.25 \mathrm{~b}$ \\
4. spent mushroom compost : rubber sawdust (1:3) & $40.10 \pm 1.42 \mathrm{c}$ & $53.25 \pm 1.29 \mathrm{~b}$ \\
5. rubber sawdust (control) & $36.05 \pm 0.78 \mathrm{~d}$ & $46.50 \pm 1.00 \mathrm{c}$ \\
\hline
\end{tabular}

Means within a column followed by same letter are not significantly different $(\mathrm{P}<0.01)$ by DMRT.

Table 2 Number of basidiocarps and yield obtained of $A$. cylindracea on different ratios of spent mushroom compost: rubber sawdust substrate.

\begin{tabular}{llll}
\hline Substrate $(\mathbf{8 5 0 g} / \mathbf{b a g})$ & $\begin{array}{l}\text { No. of } \\
\text { basidiocarps }\end{array}$ & $\begin{array}{l}\text { Yield } \\
\text { (g/bag) }\end{array}$ & $\begin{array}{l}\text { B.E. } \\
(\boldsymbol{\%})\end{array}$ \\
\hline 1. spent mushroom compost & $61.00 \pm 26.84$ & $135.63 \pm 73.29$ & $40.79 \pm 22.04$ \\
2. spent mushroom compost : rubber sawdust $(3: 1)$ & $42.29 \pm 19.11$ & $111.42 \pm 42.37$ & $33.51 \pm 12.74$ \\
3. spent mushroom compost : rubber sawdust (1:1) & $35.75 \pm 7.73$ & $97.38 \pm 34.02$ & $29.28 \pm 10.23$ \\
4. spent mushroom compost : rubber sawdust (1:3) & $35.32 \pm 11.70$ & $84.44 \pm 29.56$ & $25.40 \pm 8.89$ \\
5. rubber sawdust (control) & $31.25 \pm 5.95$ & $56.46 \pm 2.61$ & $16.91 \pm 0.78$ \\
\hline
\end{tabular}

Remark: non- significant at $\mathrm{P}<0.01$ probability levels. 




Fig. 1 - Cumulative number of basidiocarps of A. cylindracea on different ratios of spent mushroom compost : rubber sawdust substrate, during 60 days of harvesting.

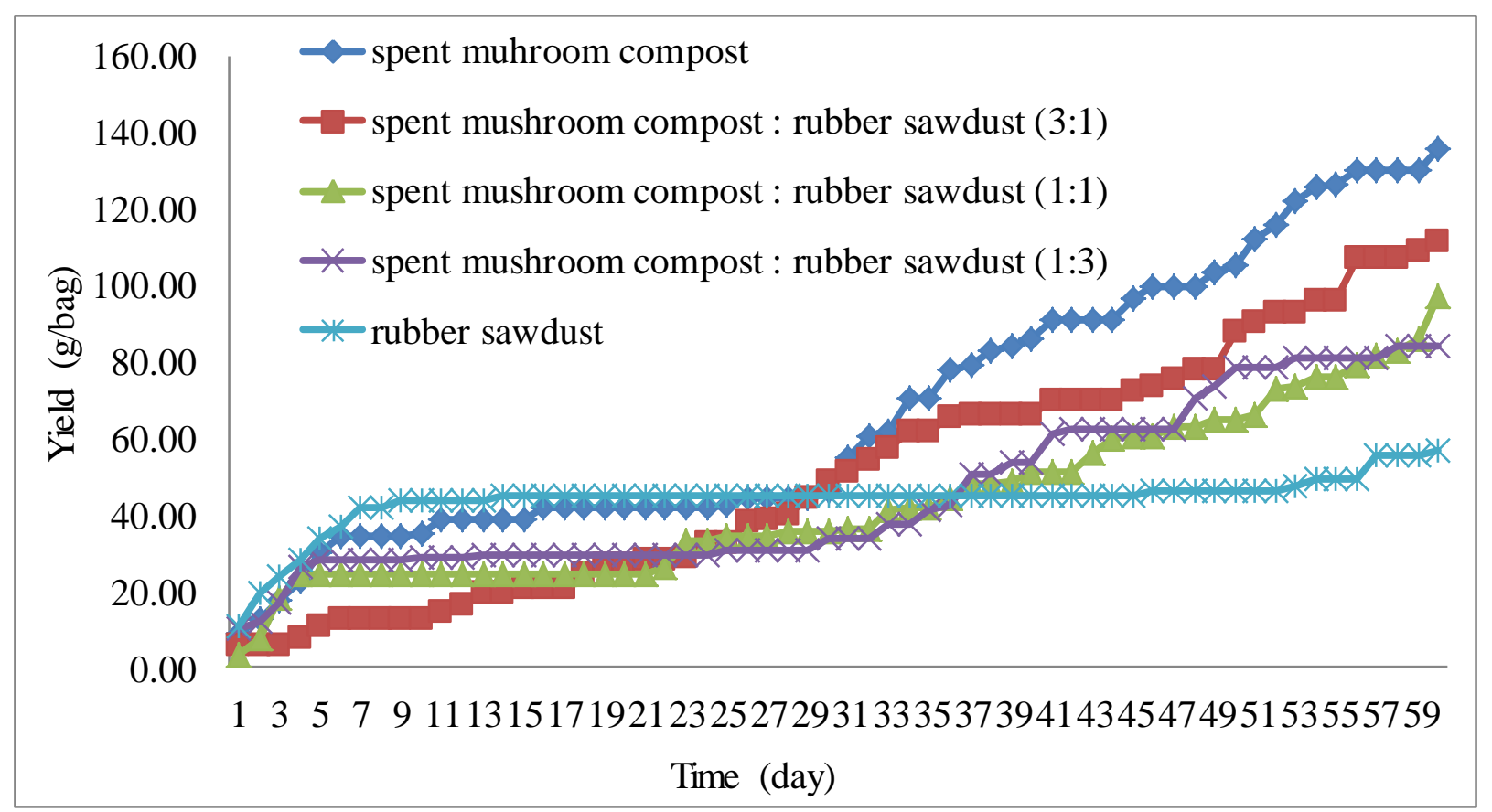

Fig. 2 - Cumulative yield of A. cylindracea on different ratios of spent mushroom compost : rubber sawdust substrate, during 60 days of harvesting. 


\section{Discussion}

In this study, the mycelium growth rate is different depending on the substrate, according to Bilay et al (2000), Obodai et al. (2003), Liang et al. (2005) investigated growth of mycelium of mushroom and reported that the rate depended on the substrate, especially Agrocybe mycelium which was easy to reproduce (Jasiniska et al. 2011). Stamets (2005) reported that Agrocybe is a common mushroom that appears on many species of trees, and the cultivation substrate is mostly chosen according to its availability. Normally, mycelial growth is a preliminary step that creates a suitable internal condition for stated fruiting bodies (Pokhrel et al. 2009). In experiments, among of the five formula substrates for the cultivation of $A$. cylindracea, the rubber sawdust (control) gave the fastest mycelial growth and time to first crop. Whereas spent mushroom compost gave the slowest mycelial growth and time to the first crop, however the yields obtained were reversed. According to Obodai et al. (2003), Liang et al. (2005) reported that period for spawn to fully colonize the substrate does not correspond with mushroom number and yield. For the results indicate that slow spawn running for A. cylindracea on rubber sawdust waste might be due to excessive nitrogen and fat contents from palm oil sludge (2.20\% Nitrogen and $15.62 \%$ Fat) which used as a supplemented in P. pulmonarius spent mushroom (Seephueak et al. 2014). According to Baysal et al. (2003) reported that slow spawn running for $P$. ostreatus on paper waste maybe due to excessive nitrogen of chicken manure. Moreover, Royse \& Rahler (1988), Jong (1989), Song et al. (1990), Fakoya et al. (2014) reported that high fat content in supplemented had effected to slow spawn running.

Liang et al. (2005) studied using mushroom sawdust wastes for cultivation of $P$. citrinopileatus and the results had shown that the period for spawn to fully colonize had significant difference among treatments use of sawdust of $M$. indica (control) gave the fastest mycelial growth rate which was 15.9 days, followed by use of sawdust mixed with sawdust waste of $P$. sajor-caju (2:1) mycelial growth rate was 18.1 days, whereas use of the substrate of sawdust waste of $L$. edodes, P. sajor-caju and sawdust mixed with sawdust waste of L. edodes gave the slowest mycelial growth rate which was 29.5-34.3 days. However, the mushroom yield was significantly greater in sawdust supplemented with $50 \%$ sawdust waste than in sawdust of $M$. indica, mushroom yield increased $20 \%$ and $6 \%$ than that of sawdust of $M$. indica only.

The results showed that number and yield of basidiocarp were reverted rate of mycelium growth, according to Obodai et al. (2003), Liang et al. (2005), Jasiṅska (2011) reported that rapidly of mycelium growth mean high yield and quality of mushroom. Philippoussis \& Diamantopoulou (2000) reported that yield of $A$. cylindracea of investigated strains was different and depended on the used cultivation substrate. Zadrazil (1994) recommended that states of better mycelium growth, as well as higher yield of Agrocybe can be obtained by increasing inorganic nitrogen content or by addition of protein rich additives in the substrate. Chen (1998) reported that the total nitrogen content in the sawdust waste increased $10 \%$ over pre-cultivation for mushroom cultivation. According to this result all formulae with used sawdust waste yields obtained higher than rubber sawdust may be due to spent mushroom compost were supplemented with palm oil sludge which high nitrogen contents.

For the experiment confirms that the spent mushroom compost was used as ingredient substrate in the cultivation of $A$. cylindracea. Where all of them showed highest yield and biological efficiency especially in the set spent mushroom compost alone. In present communication, possibilities of reuse of spent substrate were carried out for the cultivation of various mushroom species. The spent mushroom compost could be used to recultivate other edible mushroom especially Pleurotus spp. (Royse 1992, Sharma \& Jandaik 1992, 1994, Pardo-Giménez 2012, Ashrafi et al. 2014). Siddhant \& Singh (2009) studied recycling of spent oyster mushroom as a substrate for cultivation of $P$. florida strain-P1 and $P$. flabellatus and $P$. sajor-caju strain Malaysia. The result showed that mixed fresh wheat straw with $25 \%$ spent mushroom compost showed the highest yield and biological efficiency of mushroom than control. It was obtained $345 \mathrm{~g}$ (B.E.= 69\%), 565 g (B.E.=113\%) and 525 g (B.E.=105\%) for $P$. sajor-caju, $P$. florida and $P$. flabellatus, respectively. 
Sharma \& Jandaik (1985) reported recycling of Pleurotus waste for the cultivation of $P$. sajor-caju and found significant yield of $P$. sajor-caju on starch, peptone and wheat bran supplement spent mushroom substrate. Nakaya et al. (2000) reported that recycled $P$. cornucopiae waste for the cultivation of two oyster species viz., $P$. cornucopiae and $P$. ostreatus, and the results showed the high effective yield. However, Siddhant \& Singh (2009), Zhang et al. (2013), Ashrafi et al. (2014) suggest that there is a good potential for reuse of spent mushroom for the cultivation of mushroom after supplementation of certain organic and inorganic materials. Liang et al. (2005) studied using mushroom sawdust wastes of $L$. edodes and $P$. sajor-caju for cultivation of $P$. citrinopoleatus the results showed that sawdust mixed with sawdust waste (2:1) obtained the highest yield were 89.6 and $79.2 \mathrm{~g} / \mathrm{bag}$.

Zadrazil (1994) suggested that during growth on substrate, mushroom releases humic acid like fractions when added to soil which increase its fertility. In addition, humic substance may affect the reproduction of mushroom. Silva et al. (2002), Campos et al. (2009) reported that growth of mushroom on spent mushroom compost it might be due to increased mineral and protein content in spent mushroom compost which is available to fungus after supplementation. Moreover, Zhao (1993) reported that straw mushroom used a little nutrient from straw, so they were added some manure to ferment again to cultivate Coprinus mushroom in a good yield. Beside, some growers cultivated straw mushroom Volvariella with spent mushroom compost of button mushroom (Oei et al. 2007).

In Taiwan, mushroom farmers used spent king oyster mushroom substrate mixed with sawdust (1:3 to 3:4) and replace parts of new sawdust to grow king oyster mushroom, oyster mushroom, shiitake (Lentinula edodes), almond mushroom (Agaricus subrufescens) and shimeji (Hypsizigus tessellates), the mushroom yields grown with parts of spent king oyster mushroom substrate are comparable to those grown with $100 \%$ new sawdust. Moreover, shiitake grown with one-third of spent king oyster mushroom substrate has a $20 \%$ higher yield than those grown without the spent substrate (Taiwan Agricultural Research Institute 2012).

\section{Acknowledgements}

The authors thank the Division of Plant Science, Faculty of Agriculture, Rajamangala University of Technology Srivijaya, Nakhon Si Thammarat Campus for laboratory facilities.

\section{References}

Ashrafi R, Mian MH, Rahman MM, Jahiruddin M. 2014 - Recycling of spent mushroom substrate for the production of oyster mushroom. Research in Biotechnology 5, 13-21.

Baysal E, Peker H, Yalinkilic MK, Temiz A. 2003 - Cultivation of oyster mushroom on waste paper with some added supplementary materials. Bioresource Technology 89, 95-97.

Bilay VT, Solomko EF, Buchalo AS. 2000 - Growth of edible mushrooms on commercial agar media. Science and cultivation of edible fungi, van Griensven (Ed.) Balkema, Rotterdam PP, 779-782.

Campos CS, Eira AF, Minhoni MTA, Andrade MCN. 2009 - Mineral composition of raw material, substrate and fruiting bodies of Pleurotus ostreatus in culture. Interciencia 3, 432436.

Chen X. 1998 - Studies on mushroom recultivation on used compost waste. (Eds.): Lu M, Gao K, Si HF, Chen MJ. Proceedings of the 98' Nanjing International Symposium on Science and Cultivation of Mushrooms. Nanjing, China, PP. 56.

Cohen R, Persky L, Hadar Y. 2002 - Biotechnological applications and potential of wood degrading mushrooms of the genus Pleurotus. Applied Microbiology and Biotechnology 58, 582-594.

Fakoya S, Adejumo AF, Akinyele JB. 2014 - Effect of the use of Pycnanthus angolensis and different supplements on yields and on the proximate composition of Pleurotus sajor-caju. Journal of Mycology 2014, 1-4. 
Hanko J. 2001 - Mushroom cultivation for people with disabilities. A Training Manual, Food and Agriculture Organization of the United Nations Regional Office for Asia and the Pacific Bangkok, Thailand.

Isikhuemhen OS, Mikiashvili NA, Kelkar V. 2009 - Application of solid waste from anaerobic digestion of poultry litter in Agrocybe aegerita cultivation: mushroom production, lignocellulolytic enzymes activity and substrate utilization. Biodegradation 20, 351-361.

Jasinnska A, Siwulski M, Sobieralski K. 2011- Mycelium growth and yielding of Agrocybe aegerita (Brig.) Sing. on different substrates. Proceedings of the $7^{\text {th }}$ International Conference on Mushroom Biology and Mushroom Products.

Jonathan SG, Lawal MM, Oyetunji OJ. 2011 - Effect of spent mushroom compost of Pleurotus pulmonarius on growth performance of four nigerian vegetables. Mycobiology 39, 164169.

Jong BC. 1989 - Commercial cultivation of the shiitake mushroom on supplemented sawdust. Mushroom Journal for the Tropics 9, 89-98.

Kwon H, Thatithatgoon S. 2004 - Mushroom growing for a living worldwide: mushroom growing in Northern Thailand in Gush R. (eds). Mushroom Growers' Handbook1: Oyster Mushroom Cultivation, Mushroom World.

Liang ZC, Wu CY, Wang JC. 2005 - The evaluation of using mushroom sawdust wastes for cultivation of Pleurotus citrinopileatus. Journal of Fungal Science 20, 27-34.

Nakaya M, Yoneyama S, Kato Y, Harada A. 2000 - Recycling of cultural waste of Pleurotus cornucopiae for cultivation of $P$. cornucopiae and $P$. ostreatus. http://www.agro.nl/pc/isms/posters/pos106.htm (accessed 14 July 2014).

Nicolini L, Von Hunolstein C, Carilli A. 1987 - Solid state fermentation of orange peel and grape stalks by Pleurotus ostreatus, Agrocybe aegerita and Armillaria mellea. Applied Microbiology and Biotechnology 26, 95-98.

Obodai M, Cleland-Okine J, Vowotor K. 2003 - Comparative study on the growth and yield of Pleurotus ostreatus mushroom on different lignolcellulosic by-product. Journal of Industrial Microbiology and Biotechnology 30, 146-149.

Oei P, Zeng H, Liao J, Dai J, Chem M, Cheng Yi. 2007 - The alternative uses of spent mushroom compost. Innovatie Network Reports, April 2007.

Pardo-Giménez A, Picornell Buendía MR, de Juan Valero JA, Pardo-González JE, Cunha Zied D. 2012 - Cultivation of Pleurotus ostreatus using supplemented spent oyster mushroom substrate. http://www.actahort.org/members/showpdf?booknrarnr=933_33 (accessed 21 January 2016).

Philippoussis A, Diamantopoulou P. 2000 - Potential for cultivation of exotic mushroom mushroom species by exploitation of mediterranean agricultural wastes. Science and cultivation of edible fungi, van Griensven (ed.) Balkema, Rotterdam PP, 523-530.

Philippoussis A, Zervakis G, Diamantopoulou P. 2001- Bioconversion of lignocellulosic wastes through the cultivattion of the edible mushroom Agrocybe aegerita, Volvariella volvacea and Pleurotus spp. World Journal of Microbiology \& Biotechnology Research 17, 191-200.

Pokhrel CP, Yadav RKP, Ohga S. 2009 - Effects of physical factors and synthetic media on mycelial growth of Lyophyllum decastes. Journal of Ecobiotechnology 1, 46-50.

Rinker DL, ZERI, Kang SW. 2004 - Oyster mushroom cultivation. http://www.alohamedicinal.com/book1/chapter-9.pdf (accessed 21 January 2016).

Royse DJ, Rahler BD. 1988 - The effect of alfalfa hay delayed-release nutrient on biological efficiency of Pleurotus sajor-caju. Mushroom Journal for the Tropics 7, 101-106.

Royse DJ. 1992 - Recycling of spent shiitake substate for production of the oyster mushroom Pleurotus sajor-caju. Applied Microbiology and Biotechnology 38, 179-182.

Sánchez C. 2004 - Modern aspects of mushroom culture technology. Applied Microbiology and Biotechnology 64, 756-762. 
Seephueak P, Phadungmas P, Kaewmano P, Seephueak W. 2014 - Use of palm oil sludge as a supplement material for phoenix mushroom (Pleurotus pulmonarius) cultivation. Khon Kaen Agriculture Journal 42, 374-379.

Sharma VP, Jandaik CL. 1992 - Recycling of mushroom industry waste for growing Pleurotus sajor-caju and Auricularia polytricha. Indian Journal of Mycology and Plant Pathology 22, $182-186$.

Sharma VP, Jandaik CL. 1985 - Studies on recycling of Pleurotus waste. Mushroom Journal for the Tropics 6, 13-15.

Sharma VP, Jandaik CL. 1994 - Recycling of spent compost for growing Auricularia polytricha and Pleurotus species. Mushroom Information 10, 15-20.

Siddhant, Singh CS. 2009 - Recycling of spent oyster mushroom substrate to recover additional value. Kathmandu University Journal of Science Engineering and Technology 5, 66-71.

Silva SO, Costa SMG, Clemente E. 2002 - Chemical composition of Pleurotus pulmonarius (Fr.) Quel. substrates and residue after cultivation. Brazilian Archives of Biology and Technology 45, 531-535.

Song CH, Cho KY, Nair NG. 1990 - Effect of triacyglycerols on growth lipid profile and lipase activity of Lentinus edodes. Mushroom Journal for the Tropics 10, 9-19.

Sripheuk P. 2007 - Use of spent mushroom compost in a cultivation of abalone mushroom (Pleurotus abalonus Han, Chen et Cheng) and jew's ear mushroom (Auricularia polytricha (Mont.) Sacc.) in plastic bags. Khon Kaen Agricuture Journal 35, 356-363.

Stamets P. 2005 - Mycelium Running, Press. Barkeley, Toronto. supplementation to improve the biological efficiency of the edible mushroom Agrocybe cylindracea. Journal of Industrial Microbiology and Biotechnology 35, 595-602.

Taiwan Agricultural Research Institute. 2012 - Alternative substrate for growing mushrooms. http://www.tari.gov.tw/english/form/index1.asp?Parser=20,15,926,81,,,3007,192,,,3,17. (accessed 14 June 2014).

Thawthong A, Karunarathna SC, Thongklang N, Chukeatirote E, Kakumyan P, Chamyuang S, Rizal LM, Mortimer PE, Xu J, Callac P, Hyde KD. 2014 - Discovering and domesticating wild tropical cultivatable mushrooms. Chiang Mai Journal of Science 41, 731-764.

Uhart M, Piscera JM, Albertó E. 2008 - Utilization of new naturally occurring strains and supplementation to improve the biological efficiency of the edible mushroom Agrocybe cylindracea. Journal of Industrial Microbiology and Biotechnology 35, 595-602.

Zadrazil F. 1994 - Cultivation of Agrocybe aegerita (Brig.) Sing. on lignocellulose containing waster. Mushroom Information 10, A5-22.

Zhang W, Niu X, Zhang W, Liu Z, Yuan S. 2013 - The cultivation of Agaricus bisporus on the spent substrate of Flammulina velutipes. African Journal of Agricultural Research 8, 4860 4863.

Zhao ZH. 1993 - Cultivation of Coprinus comatus on spent straw mushroom compost. Edible Fungi of Zhejiang, No. 2-13. 